\title{
Macunahyphes : a New Genus for Tricorythodes australis (Ephemeroptera : Leptohyphidae)
}

\author{
L.G. Dias ${ }^{1}$, F.F. Salles ${ }^{1 *}$, C. Molineri ${ }^{2}$ \\ ${ }^{1}$ Museu de Entomologia, Departamento de Biologia Animal, Universidade Federal de Viçosa, MG, Brazil. \\ 2 INSUE-CONICET-Facultad de Ciencias Naturales, Universidad Nacional de Tucumán, Argentina.
}

\begin{abstract}
Macunahyphes, gen. nov. is proposed to include Tricorythodes australis (Banks). In the present paper, the new taxon is described an illustrated from imagos and nymphs. The unique characters present in Macunahyphes gen. nov. are: in the male imago, (1) forceps tri-segmented with first segment distomedially projected, (2) penis with very wide base, becoming thinner toward a subapical constriction, and then slightly widening again, penis lobes of each side almost completely fused except apical insicion, (3) penes with a ventral projection covered with spines, and in the nymph, (4) glossae and paraglossae almost completely fused, with a circular outline, and (5) femora with numerous robust serrate setae.
\end{abstract}

Keywords : Macunahyphes australis, new genus, Tricorythodes, taxonomy, Neotropics.

\section{Introduction}

Tricorythodes Ulmer is a Panamerican genus of Leptohyphidae (Ephemeroptera : Ephemerelloidea) with 15 species recorded from South America. Although the genus is a well-defined group supported by numerous characters (Molineri 2002), one of its species, $T$. australis (Banks), has always being suggested as an unusual member of the genus (Traver 1958, Molineri 2002). Tricorythodes australis was originally described by Banks (1913), as Tricorythus australis, based on adults from Rio Madeira, Brazil North Region. Later, Ulmer (1920) transferred it to Leptohyphodes Ulmer, and Traver (1958) revised the species based on the type-material and additional adults from British Guiana. According to Traver (1958), the species was in fact an aberrant member of the genus Tricorythodes, with several characteristics differing from other members of the genus, such as : absence of the basal swelling of the second joint of the forceps, absence of the

* Corresponding author : E-mail : ffsalles@gmail.com longitudinal vein $\mathrm{CuP}$ on male forewings, and form and structure of the penis.

According to Molineri (2002), in his cladistic analysis of the South American species of Tricorythodes, the position of T. australis in the cladogram, though not fully determined, was basal to all but one species of Tricorythodes. Based on these facts, Molineri (2002) advocated that, despite the possibility that $T$. australis did not belong to Tricorythodes, it was inconvenient to erect a new genus until the nymphs were known.

Recently, among material collected in several areas of the state of Roraima, Northern Brazil, an unusual Tricorythodes-like nymph was found. The posterior study of a male mature nymph and associated adults of the same area, revealed us that these nymphs were in fact the unknown immature stage of T. australis. In the present paper, based on some remarkable characteristics of these nymphs, and the distinctiveness of the adults, Macunahyphes new genus is proposed to include T. australis. 


\section{Material and methods}

The material used was preserved in $80 \%$ ethanol. Body parts of nymphs and adults were mounted in glycerin on microscope slides and drawn with a camera lucida attached to a stereo microscope. Mouthparts, legs and genitalia were extracted, dehydrated in a graded ethanol series, dried by critical point-method, and then mounted on SEM stubs and sputter coated with gold; then observed and photographed with Zeiss VP30X scanning electron microscope. Terminology of thoracic structures follows Kluge (1992). Material deposition is abbreviated as follows : Invertebrate Collection of the Instituto Nacional de Pesquisas da Amazônia, Brasil (INPA), Instituto-Fundación Miguel Lillo, Tucúman, Argentina (IFML).

Macunahyphes, gen. nov.

Type species. Tricorythus australis Banks, 1913:85, original designation.

Species included : Macunahyphes australis (Banks, 1913) comb. nov.

Etymology : the generic name is an arbitrary combination of the words Macunaima, Divine entity for several indigenous people from Roraima (the state where the nymphs were found), and hyphes, reticulate or webbed, commonly used in leptohyphid generic names.

\section{Description}

Imago. Length of male : body : $2.8 \mathrm{~mm}$; fore wings : $2.5 \mathrm{~mm}$. Length of female : body : $3.0 \mathrm{~mm}$; fore wings : $2.5 \mathrm{~mm}$.

Head. Eyes of male simple, relatively small. Antennae twice the length of head capsule; pedicel twice the length of scape ; head at base of antennae dorsally expanded. Thorax. Mesonotum with anteronotal projection subquadrangular, prominent. Median and lateral parapsidal sutures merged anterior to transversal interscutal suture. Membranous filaments of mesoscutellum absent. Superior interscutal suture of lateropostnotum forming a straight line with the inferior interscutal suture. Hind wings absent in both sexes ; forewing with $\mathrm{Cu}-\mathrm{A}$ lobe enlarged in both sexes, especially in males ; longitudinal vein $\mathrm{CuP}$ poorly developed or absent in both sexes (Figs. 1,2). Apex of mid and hind tibiae ventrally extended. Abdomen. Genitalia : Styliger plate slightly convex, somewhat projected at base of forceps. Forceps tri-segmented, distally divergent ; ratio length of segment/total length of forceps : first segment 0.4 , second segment 0.5 , and third segment 0.1 ; first segment distomedially projected ; se- cond segment long, flattened at base, narrower toward apex ; third segment small and circular (Fig. 23). Penis wide at base, with ventral projection covered with spines (Figs. 20-22). Female IX sternum posteriorly projected, with truncated apex. Caudal filaments at least 4 times longer than body in male, shorter than abdomen in female. Female cerci shorter than terminal filament, bare.

Nymph. Length of male : body, $2.8 \mathrm{~mm}$; mesonotum, $0.8 \mathrm{~mm}$; terminal filament, $1.5 \mathrm{~mm}$; cerci $1.9 \mathrm{~mm}$. Length of female : body, $3.5 \mathrm{~mm}$; mesonotum, $0.8 \mathrm{~mm}$; terminal filament, $2.0 \mathrm{~mm}$; cerci $2.0 \mathrm{~mm}$.

Head. Genal projections small (Fig. 3). Antennae approximately two times longer than maximum width of head (Fig. 3). Anterior margin of labrum with long setae and deeply cleft medially (Fig. 4). Mandibles with long setae on dorsum and outer margins (Figs. 5, 6, $25)$; outer incisors with row of small setae. Maxillae with long setae (Figs. 7, 25), distal brush restricted to apex of galea-lacinia (Fig. 26), internal margin of maxillae with robust setae and dentisetae, oriented medially ; galea-lacinia long, completely fused and with parallel sided margins; maxillary palp small (Figs. 7, 25, 27), unsegmented and with apical seta. Hypopharynx as in Fig. 8 ; labium with submentum laterally rounded, with anterolateral corners projected and margins fringed with setae ; labial palpi tri-segmented, with long setae, segment 1 three times longer than segment 2, segment 2 and 3 subequal in length (Fig. 9); glossae and paraglossae almost completely fused, with a rather circular outline (Fig. 10). Thorax. Legs : dorsum of fore femora with a transversal row of small to long robust (Figs. 11, 28), serrate setae (Fig. 30), dorsum of mid and hind legs with 3 longitudinal rows of small to long robust (Fig. 29), serrate setae ; tibiae of all legs with two rows of setae on inner margin, tarsi with one row of setae on inner margin; fore and mid femora subequal in length, hind femora $20 \%$ longer than fore femora (Figs.11-13) ; tarsal claws with 7-10 marginal denticles, with two rows of submarginals denticles, one side with 2 and the other with 4 denticles, and with subapical setae (Fig. 31). Abdomen. Posterior margin of terga 2-5 smooth (Fig. 32), other segments with denticles ; posterior margin of terga 2-6 with 4 to 6 long, robust setae (Fig. 32), posterior margin of tergum 7 with longer and more numerous robust setae ; abdominal segments 3-6 expanded laterally, abdominal segments 7-9 with posterolateral spines (Fig. 33). Operculate gills subtriangular (Fig. 14) ; gills 2-5 composed of 3 lamellae, gills 6 composed of 2 lamellae (Figs. 15-19). Terminal filament shorter than body, slightly longer than cerci. 

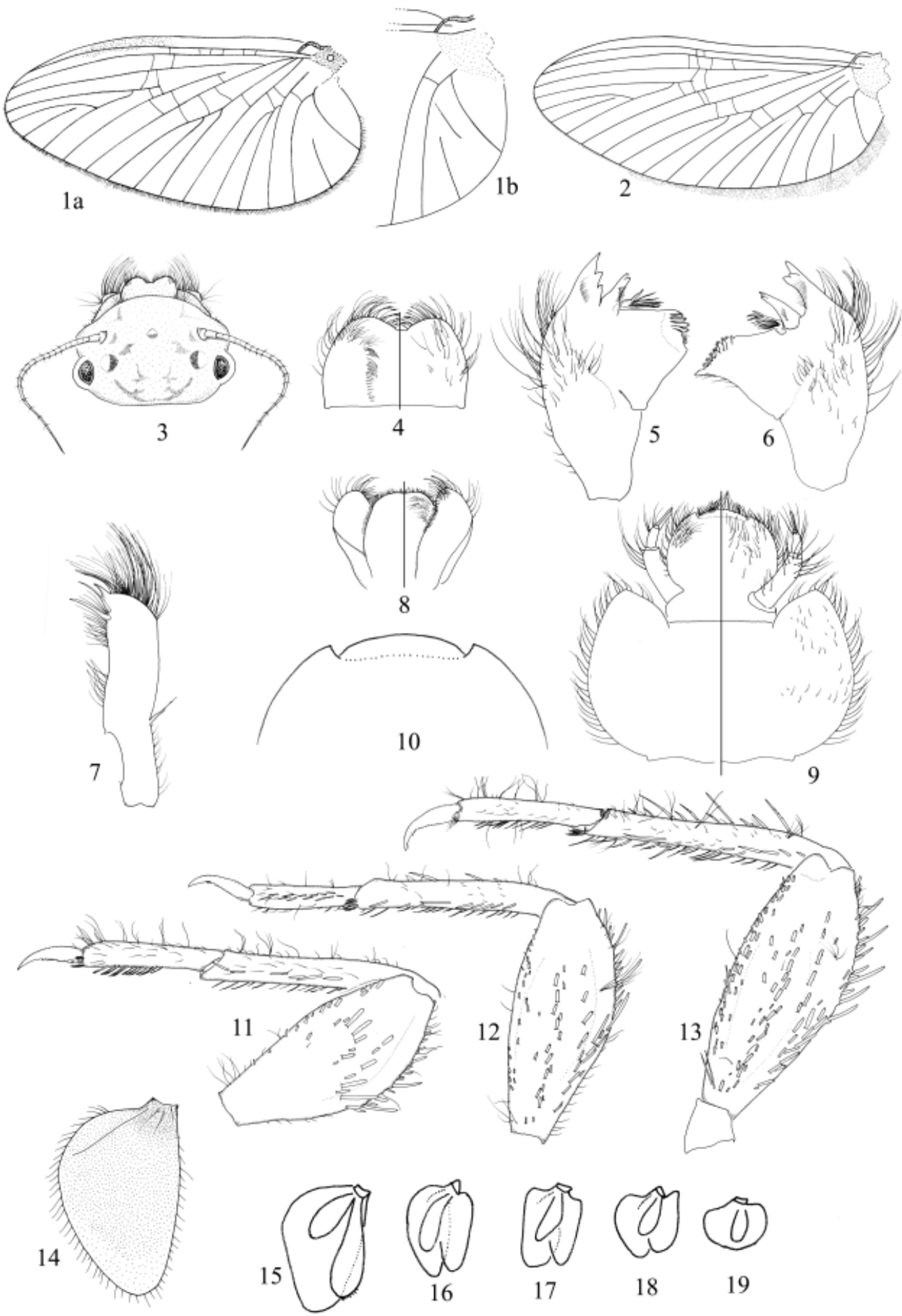

Figs 1-19. Macunahyphes australis (Banks), comb. nov. : 1a. Forewing of male imago. 1b. Forewing of male imago (detail of cubito-anal area). 2. Forewing of female imago. 3. Head (dorsal view). 4. Labrum (dorsal view). 5. Left mandible (dorsal view). 6. Right mandible (dorsal view). 7. Maxilla (dorsal view). 8. Hypopharynx. 9. Labium (ventral view). 10. Labium (detail of glossae and paraglossae, ventral view). 11. Foreleg. 12. Mid leg. 13. Hind leg. 14. Gill II (dorsal view). 15-19. Gills II-VI (ventral view). 


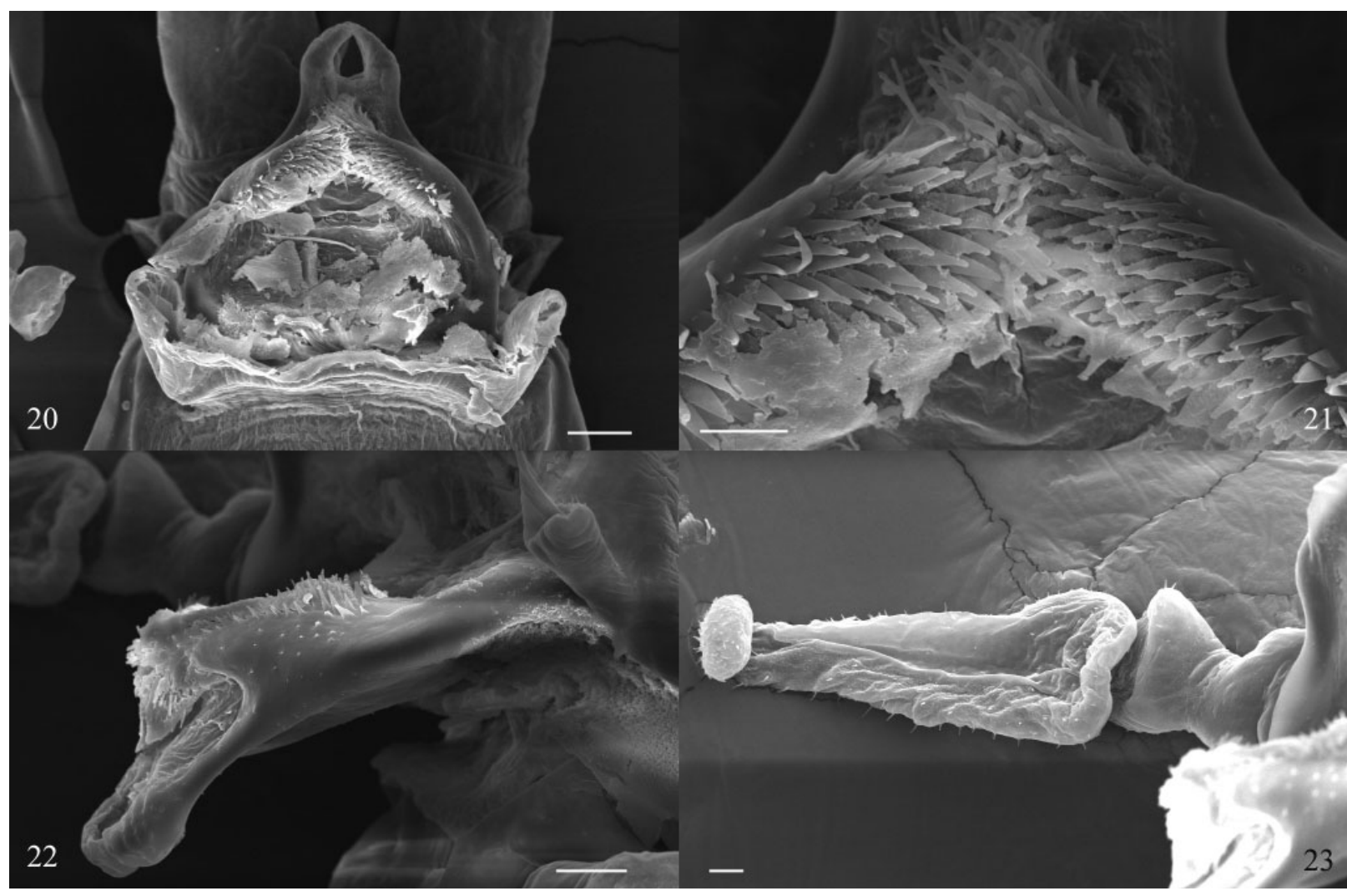

Figs 20-23. Macunahyphes australis (Banks), comb. nov.: 20. Penis (ventral view). 21. Penis (detail of spines, ventral view). 22. Penis (lateral view). 23. Forceps (lateral view). Scale bars $=10 \mu \mathrm{m}$ (Figs. 21, 23), $20 \mu \mathrm{m}$ (Fig. 22), $30 \mu \mathrm{m}$ (Fig. 20).

Eggs. (Figs. 34-35). Length, $130 \mu \mathrm{m}$; Maximum width, $70 \mu \mathrm{m}$. One polar cap present, flattened, apically rounded. One micropylar area present, subcircular, bordered by six chorionic plates (Fig. 35). Chorionic plates contiguous, with lateral borders of one side elevated, narrow (Fig. 35). Adhesive filaments absent (except on polar cap).

Diagnosis. Unique characters present in Macunahyphes gen. nov. are : in the male imago, (1) forceps tri-segmented with first segment distomedially projected (Fig. 23), (2) penis with very wide base, becoming thinner toward a subapical constriction, and then slightly widening again, penis lobes of each side almost completely fused except apical incision (Fig. 20), (3) penis with a ventral projection covered with spines (Figs. 20-22), and in the nymph, (4) glossae and paraglossae almost completely fused, with a circular outline (Figs. 9, 10), and (5) femora with numerous robust serrate setae (Figs.11-13, 28-29).

Macunahyphes gen. nov. can be distinguished from the other genera of Leptohyphidae by the characters listed above and the following combination of characters: in the imago, (1) eyes similar in both sexes, undivided ; (2) forewings with well developed CU-A lobe, especially in males ; longitudinal vein CuP poorly developed in both sexes or absent in males (Figs.1, 2) ; (3) hind wings absent in both sexes ; (4) membranous filaments of mesoscutellum absent; and (5) styliger plate very slightly projected posteriorly as a columnar base for each forceps. In the nymphs : (1) maxillary palp reduced in size, one-segmented with apical seta (Figs. 7, 25, 27), (2) tarsal claws long and slender, with 7-10 marginal denticles and a double row of 2-4 submarginal denticles (Fig. 31), (3) gills present on abdominal segments II-VI, gill formula 3/3/3/3/2 (Figs.14-19), (4) operculate gills subtriangular (Figs. 14), and (5) posterior margin of terga 2-5 smooth, other segments with denticles (Fig. 32). 


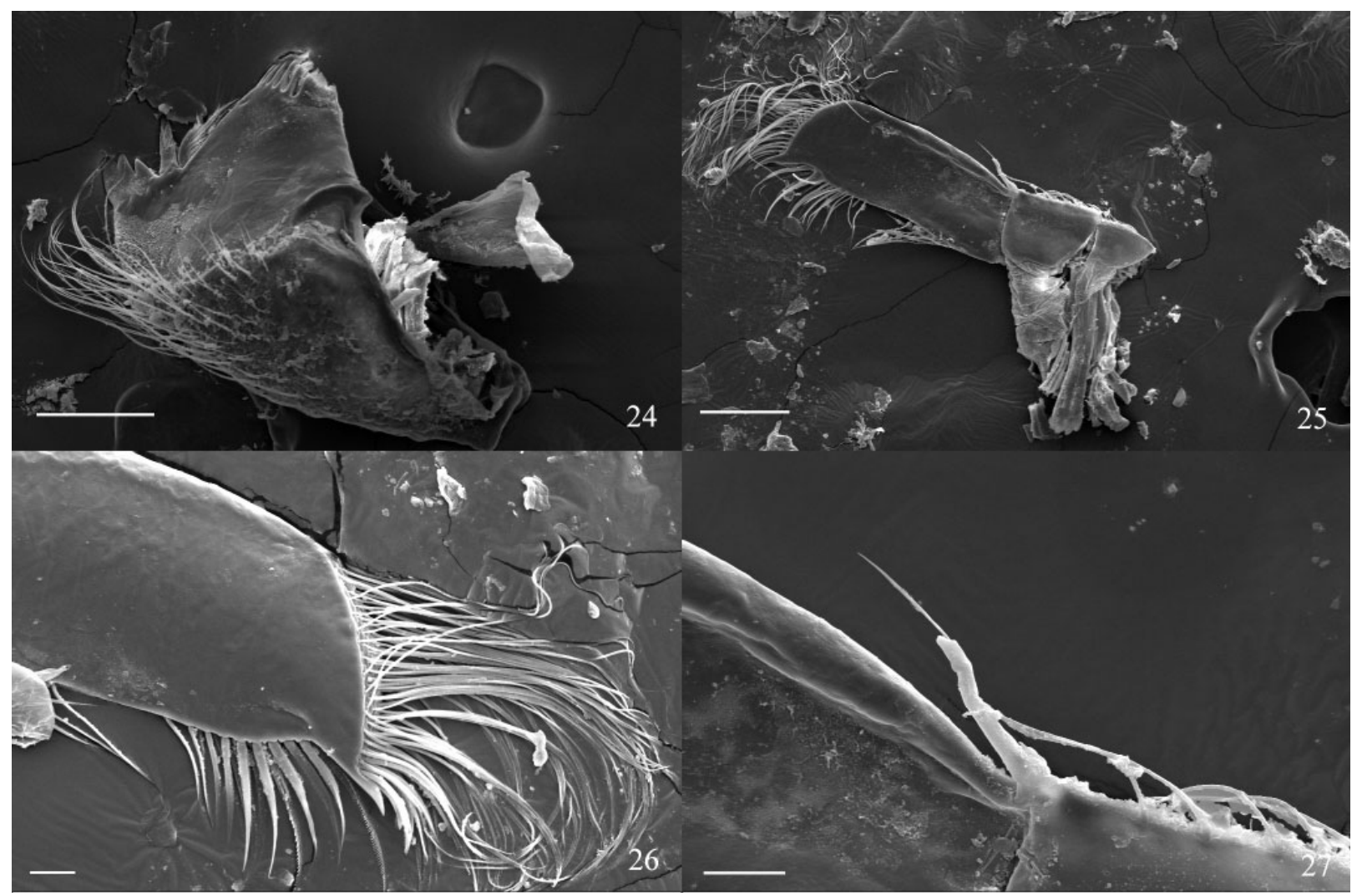

Figs 24-27. Macunahyphes australis (Banks), comb. nov. : 24. Mandible (dorsal view). 25. Maxilla (dorsal view). 26. Maxilla (detail of apex, dorsal view). 27. Maxilla (detail of maxillary palp, dorsal view). Scale bars $=20 \mu \mathrm{m}$ (Figs. 26, 27), 100 $\mu \mathrm{m}$ (Fig. 24, 25).

\section{Discussion}

With the discovery of the nymphs of Macunahyphes australis comb. nov., the differences from this species in relation to the other species of the genus Tricorythodes became more evident. The study of the nymphal mouthparts revealed that there is a incompatibility between the existent concept of Tricorythodes and M. australis, mainly concerning features of maxilla and labium. Although the mouthparts resemble those of the genus Haplohyphes Allen, the glossae and paraglossae almost completely fused, among other characters listed above separate $M$. australis from species placed in the genus Haplohyphes. In adults, the absence of the swelling on the second segment of the forceps, and the penis with a ventral projection covered with spines, support the distinction between Macunahyphes and Tricorythodes.

Macunahyphes australis (Banks), comb. nov.

Tricorythus australis Banks, 1913 : 85
Leptohyphodes australis - Ulmer, 1920 : 50

Tricorythodes australis - Traver, 1958 : 501-503 ; Molineri, 2002 : 278

Male imago. General coloration yellowish. Head. Coloration whitish yellow shaded with gray posteriorly, medially shaded with light gray. Antennae grayish yellow. Rest of mouthparts yellowish shaded with black. Thorax. Prothorax translucent ; pronotum shaded with dark gray on median zone and lateral margins; pterothorax yellowish with blackish marks between posterior scutal protuberance ; mesoscutellum yellowish shaded with black; mesopleurae with a black sinuous line on median area. Legs whitish yellow; trochanters of all legs with a small blackish mark. Membrane of wings shaded with gray; costal area and longitudinal veins dark gray. Abdomen. Whitish yellow translucent, except segments 9-10 whitish ; tergum I and median zone of terga 2-6 shaded with light gray ; terga 2-6 with lateral margins shaded with gray. Genitalia : penis whitish, stytiliger plate and ventral 


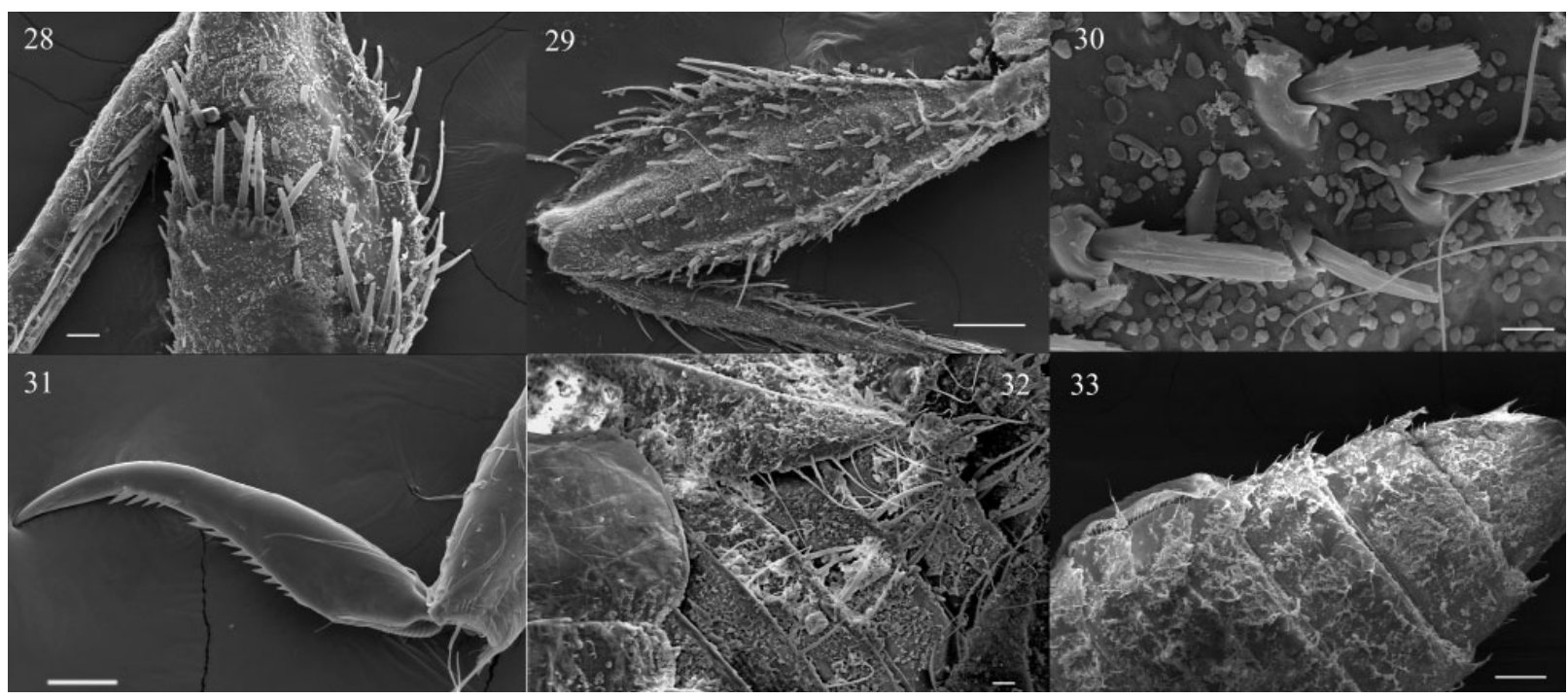

Figs 28-33. Macunahyphes australis (Banks), comb. nov. : 28. Fore femora (dorsal view). 29. Mid femur (dorsal view). 30. Mid femur (detail of serrate spines). 31. Fore tarsal claw. 32. Abdomen (detail of segments I-V, dorsal view). 33. Abdomen (ventral view). Scale bars $=10 \mu \mathrm{m}$ (Fig. 30), $20 \mu \mathrm{m}$ (Fig. 32), $30 \mu \mathrm{m}$ (Fig. 28, 31), $100 \mu \mathrm{m}$ (Figs.29, 33).
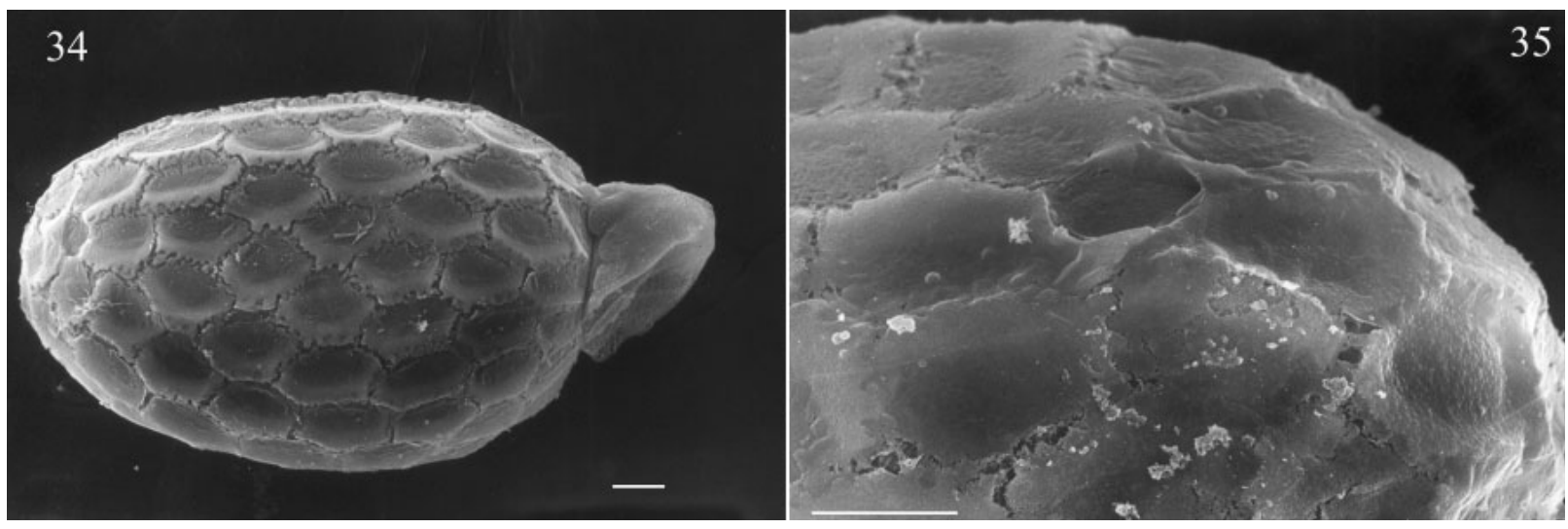

Figs 34-35. Macunahyphes australis (Banks), comb. nov. : 34. Eggs (general view). 35. Eggs (detail of micropile and chorionic plates). Scale bars $=10 \mu \mathrm{m}$.

projection of penis yellowish, forceps whitish. Caudal filaments : cerci whitish, first segments shaded with black ; terminal filament completely shaded with black. Female imago. As in male except usual sexual dimorphism, grayish marks slightly darker. Eggs yellowish. Caudal filaments whitish translucent.

Nymph. General coloration yellowish with blackish marks. Head. Yellowish with blackish marks on posterior margin, between ocelli and base of antennae (Fig. 3). Antennae yellowish. Mouthparts. Labrum yellowish. Mandibles yellowish, becoming darker toward apex. Maxillae yellowish. Hypopharynx dark yellowish, becoming lighter toward apex. Labium yellowish. Thorax. Pronotum yellowish with blackish marks on lateral and median regions ; mesonotum yellowish with blackish diffuse marks on median zone, mesoescutellum and base of developing wings ; pleurae yellowish shaded with black; sterna yellowish with margins shaded with gray. Legs yellowish. Abdomen. Yellowish shaded with black, segments bearing gills darker, especially underneath gills. Terga VI-IX generally without marks, sometimes with blackish diffuse marks 
on median and lateral zone. Sterna whitish yellow. Gills : operculate lamellae subtriangular ; coloration of operculate lamellae grayish, with dark gray apex, lateral margins grayish translucent ; remaining gills completely shaded with light gray.

\section{Diagnosis and discussion}

As Macunahyphes gen. nov. is, for the moment, a monotypic genus, the characters used in the generic section should be used also for specific diagnosis.

Material examined. 20 nymphs, Brazil, Roraima state, Caracaraí, Cachoeira Bem Querer, 23/iii/2001, N. Hamada leg. (10 nymphs in INPA, 10 in IFML) ; 15 male and 5 female imagines, same data, except 1821/i/2002, A.M.O. Pes leg., Pennsylvania light trap (INPA) ; 47 male and 3 female imagines (eggs from SEM extracted from one of these females) from Brazil, Pará, R. Trombetas, prox. L. do Moura, 6/x/1969 (27 males and 1 female in MZSP, rest in IFML). The material listed in Molineri (2002) was also studied.

\begin{abstract}
Acknowledgements
We are grateful to Núcleo de Microscopia e Microanálise da Universidade Federal de Viçosa, and Dr. José E. Serrão, for making available the scanning electron microscope, and to Dr. Neusa Hamada and Ana M. O. Pes (Instituto Nacional de Pesquisas da Amazônia) for supplying the specimens. We also thank the $\mathrm{CNPq}$ for providing funds to FFS and LGD to conduct graduate studies at the Universidade Federal de Viçosa ; and the CONICET for financial support to $\mathrm{CM}$.
\end{abstract}

\section{References}

Banks N. 1913. - The Stanford Expedition to Brazil. 1911. Neuropteroid insects from Brazil. Psyche, 20, 83-89.

Kluge N.J. 1992. - Redescription of Leptohyphes eximius Eaton and diagnoses of the genera Leptohyphes and Tricorythodes based on the structure of pterothorax (Ephemeroptera : Tricorythidae, Leptohyphinae). Opusc. Zool. fllumin., 98, 1-16.

Molineri C. 2002. - Cladistic analysis of the South American species of Tricorythodes (Ephemeroptera : Leptohyphidae) with the descriptions of new species and stages. Aquat. Insects, 24(4), $273-$ 308.

Traver J.R. 1958. - The subfamily Leptohyphinae (Ephemeroptera :Tricorythidae). Part I. Ann Entomol. Soc. Amer., 51 : 491-503

Ulmer, G. 1920. - Neue Ephemeropteren. Arch. Naturgesch., 85(11), $1-80$ 